\title{
Simultaneous determination of methanol, ethanol and isopropanol in human blood and white spirit samples
}

\author{
Vu Anh Phuong ${ }^{*}$, Nguyen Thi Ngan ${ }^{1}$, Do Thi Trang ${ }^{1}$ \\ Dinh Son Luong ${ }^{1}$, Nguyen Thi Anh Huong ${ }^{2}$,Hoang Quoc Anh ${ }^{* *}$ \\ ${ }^{1}$ Poison Control Center, Bach Mai Hospital, Hanoi, Vietnam \\ ${ }^{2}$ University of Science, Vietnam National University, Hanoi, Vietnam
}

(Received: 13/11/2020; Accepted: 21/12/2020)

\section{Abstract}

A simple and cost-effective method for simultaneous determination of methanol, ethanol, and isopropanol in human blood and white spirit samples using headspace gas chromatography coupled with flame ionization detection (HS-GC-FID) was developed and validated for clinical and toxicological purposes. In this study, the headspace sampling procedure was investigated, indicating optimized temperature of $70^{\circ} \mathrm{C}$ in $20 \mathrm{~min}$. Concentrations of target compounds were determined by internal standard (IS) method with acetonitrile as IS compound. A good resolution of chromatographic peaks was achieved. The linear ranges for all the compounds were from 1 to $500 \mathrm{mg} / \mathrm{dL}$. Our method was validated with adequate accuracy (recovery > $98 \%)$ and precision $(\mathrm{RSD}<0.1 \%)$ in whole human blood and white spirit samples. The limits of detection were below $0.5 \mathrm{mg} / \mathrm{L}$ for the three compounds. This method is easy to perform, making it suitable for routine analysis in clinical biochemistry and forensic laboratories.

Keywords: Methanol, ethanol, isopropanol, blood, white spirit, GC-FID.

\section{INTRODUCTION}

Methanol, ethanol, and isopropanol are three of the most common alcohols and are widely used in industries and livelihoods. Ethanol can be used as a drink but methanol and isopropanol are toxic to humans. Ingestion of small amounts of methanol may cause headache, vertigo, nausea, vomiting, blindness, and even death. Consumption of $20 \mathrm{~mL}$ and $60 \mathrm{~mL}$ of methanol can cause blindness and death, respectively [1]. In the Poison Control Center of Bach Mai Hospital, numbers of methanol poisoning patient increase over recent years. There were 14, 33,46 , and 80 cases recorded in this center in the years 2014, 2015, 2016, and 2017, respectively. Consumption of fake white spirit is one of main reasons for this situation.

Several methods have been developed to detect methanol, ethanol, and isopropanol in beverage products, such as colorimetric method, titrimetric method [2], high performance liquid chromatography (HPLC) [3], voltametric method [4-5], and gas chromatography (GC) [7-11]. Among them, GC is a precise and reliable method for the determination of low-molecularweight alcohols in blood and other biological fluids and has become a reference method in forensic and clinical toxicology. Headspace GC (HS-GC) is now the most widely used technique for the detection of volatile organic compounds in biological fluids, mainly due to its sensitivity, selectivity, and simplicity (e.g., without various sample preparation steps).

\footnotetext{
${ }^{*}$ Corresponding author: Tel: 0912134373

Email:vuanhphuong86@gmail.com

** Co-corresponding author: Tel: 0868223383

Email: hoangquocanh1990@gmail.com
} 
In this study, a simple, rapid, and inexpensive procedure utilizing HS-GC with flame ionization detection was established to simultaneously determine methanol, ethanol, and isopropanol in biological specimens and white spirit samples. The validated analytical procedure has been also used as routine testing at the Poison Control Center of Bach Mai Hospital.

\section{MATERIALS AND METHODS}

\subsection{Chemicals and standards}

All the chemicals used in this study are of analytical grade and were purchased from Merck (Darmstadt, Germany): ethanol (> 99.9\%), methanol (> 99.9\%), isopropanol (> 99\%), acetonitrile (>99.9\%), and sodium chloride $(\mathrm{NaCl})$. Deionized water for preparation of all the solutions was purified (18.2 MW).

\subsection{Preparation of calibration curve standards}

Six concentration levels of the calibration standards were prepared with individual concentrations of methanol, ethanol, and isopropanol as 1, 10,50,100,250, and $500 \mathrm{mg} / \mathrm{dL}$.

\subsection{Sample preparation}

A 1-mL aliquot of whole blood was pipetted into a $20 \mathrm{~mL}$ crimped headspace vial, spiked with $3 \mathrm{~mL}$ of $10 \mathrm{mg} / \mathrm{dL} \mathrm{ACN}$ solution in $\mathrm{NaCl} 10 \%$ as internal standard and then $1 \mathrm{~mL}$ deionized water. The glass vial was sealed with a Teflon-lined silicone septum and an aluminum cap (Agilent Technologies). The prepared solution was lightly mixed manually and placed in the headspace autosampler.

\subsection{Headspace conditions}

The automated headspace autosampler 7697A (Agilent Technologies) was interfaced with the GC-FID for sample preparation and sample introduction into the GC. The samples were stirred and incubated in the oven for $15 \mathrm{~min}$ at $70^{\circ} \mathrm{C}$.

\subsection{GC-FID conditions}

All analyses were performed on a GC-8890 gas chromatograph (Agilent Technologies) equipped with a DB-BAC 2 UI column $(30 \mathrm{~m} \times 0.32 \mathrm{~mm} \times 1.2 \mu \mathrm{m})$ and two FIDs that operated under the same conditions. Helium (99.9992\%) was employed as carrier gas. The oven temperature was held at $45^{\circ} \mathrm{C}$ for $6 \mathrm{~min}$. The instrument parameters were as follows: inlet temperature $210^{\circ} \mathrm{C}$, detector temperature $250^{\circ} \mathrm{C}$, and carrier gas flow rate $35 \mathrm{~mL} / \mathrm{min}$. Samples were injected in the split mode (1:10) [4].

\section{RESULTS AND DISCUSSIONS}

\subsection{Optimization of headspace conditions}

The incubation temperature and time are important factors influencing the diffusion behavior of substances into the vapor phase and therefore affecting sensitivity. However, very high incubation temperature and long incubation time may lead to the evaporation of solvent and some volatile interferences, which may negatively affect the detection of target compounds. We investigated the effects of incubation temperature $\left(50\right.$ to $80^{\circ} \mathrm{C}$ ) and time (5 to $25 \mathrm{~min}$ ), and the results are presented in Figure 1 and Figure 2, respectively. In these experiments, the onepoint standard addition method was used to calculate recovery of the target compounds. The 
recoveries ranged from 90 to $110 \%$ at temperature from 70 to $80^{\circ} \mathrm{C}$. However, incubation at $80^{\circ} \mathrm{C}$ leaded to increase baseline and make peak assignment difficult. Therefore, incubation at $70^{\circ} \mathrm{C}$ was chosen to ensure the sensitivity and to avoid baseline rising.

Similar to the effect of sample incubation temperature, if the incubation time is too short, the ability to diffuse substances into vapor phase will be not enough, leading to low recovery. However, recoveries did not increase significantly after $25 \mathrm{~min}$. As a result, incubation time of 20 min was selected because of adequate recoveries (>90\%) and time savings.

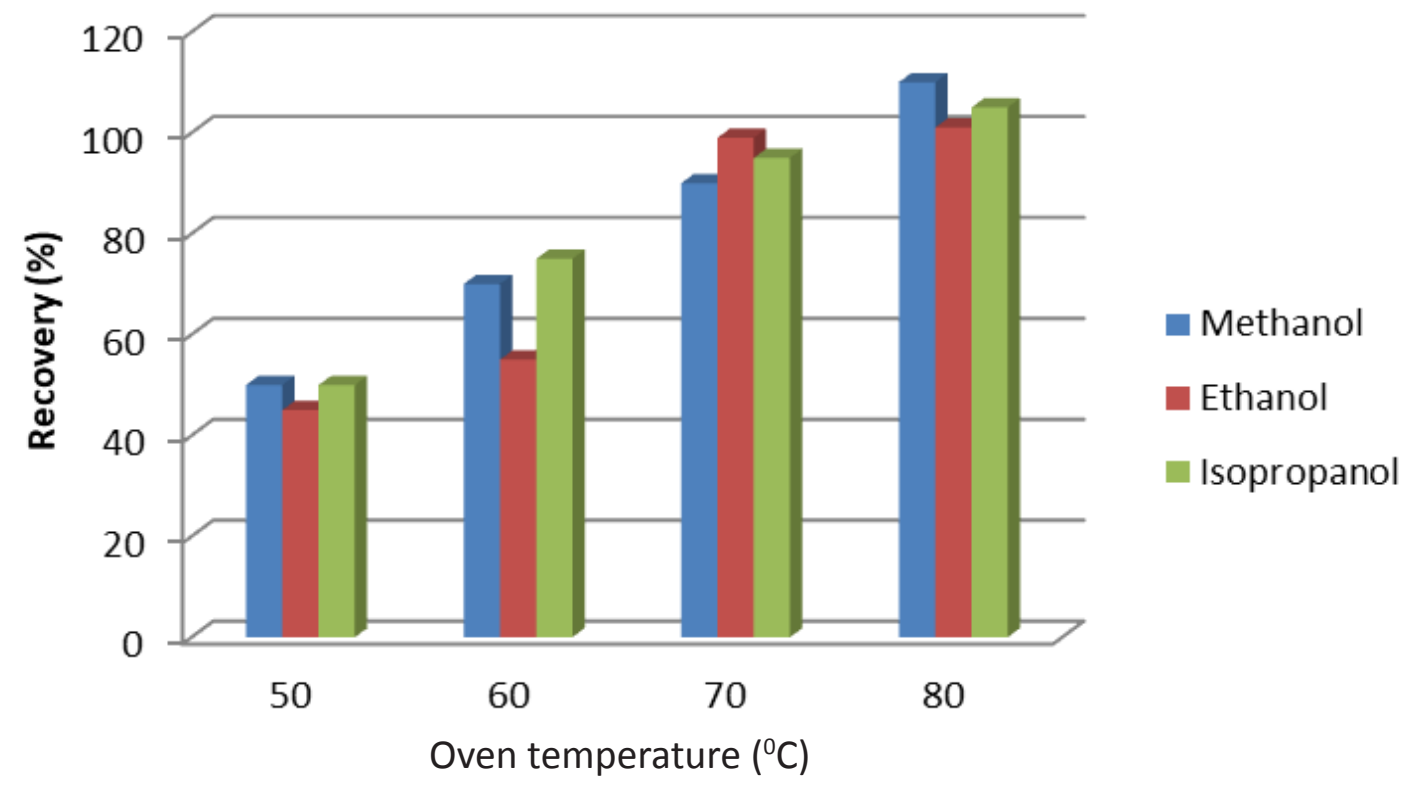

Figure 1. The recovery of methanol, ethanol, and isopropanol with different oven temperatures

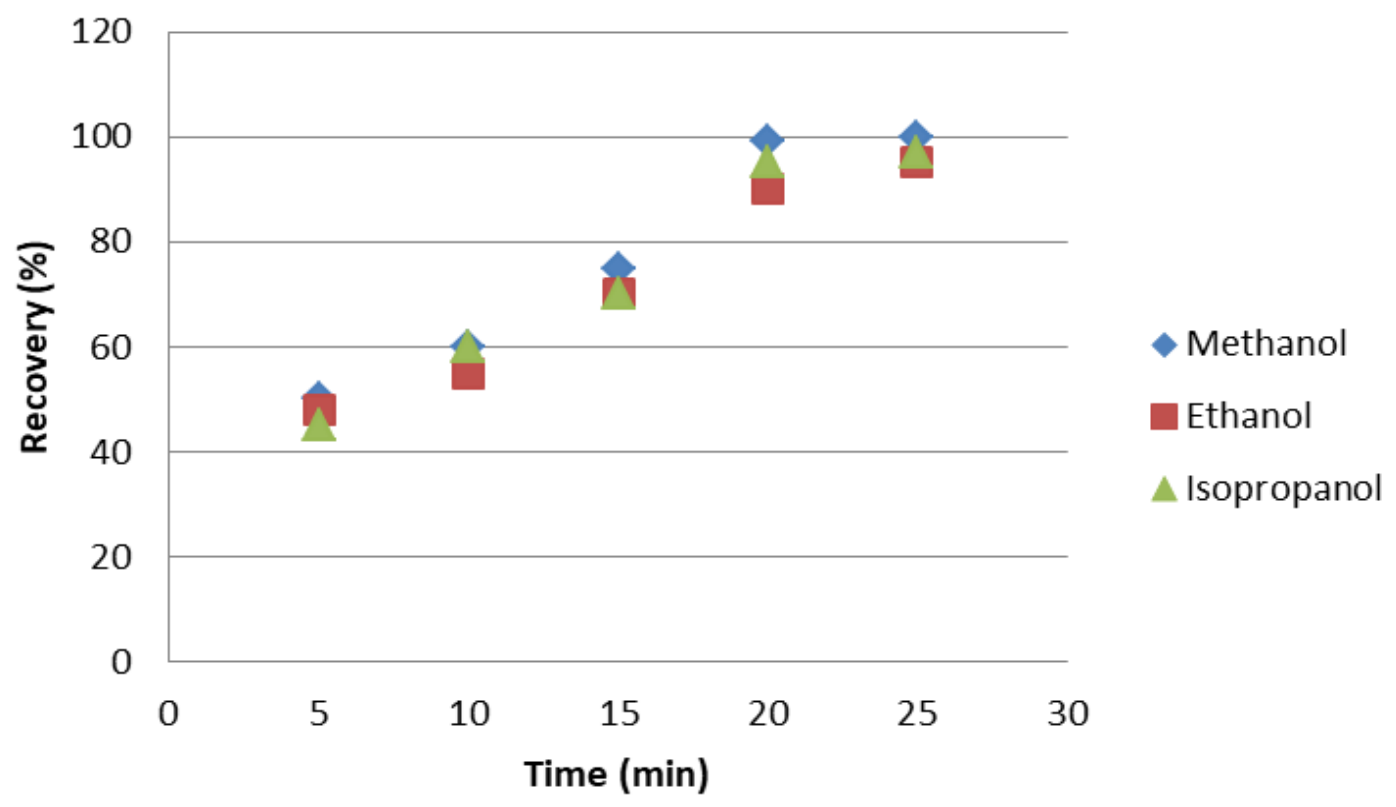

Figure 2. The recovery of methanol, ethanol, and isopropanol with different incubation times 


\subsection{Optimization of oven temperature}

The oven temperature program significantly affects the retention time and separation efficiency in GC. We investigated oven temperatures from 35 to $85^{\circ} \mathrm{C}$ and the results are shown in Figure 3. It is clear that higher oven temperature can reduce retention time of all the compounds. However, if the temperature rises above $55^{\circ} \mathrm{C}$, the resolution between some analytes will be decreased, especially in high-concentration standards (e.g., $>50 \mathrm{mg} / \mathrm{dL}$ ). The best separation was obtained at the temperature of $45^{\circ} \mathrm{C}$. The resolution between the peaks is higher 1.5 for all compound couples. Therefore, the optimal oven temperature is $45^{\circ} \mathrm{C}$.

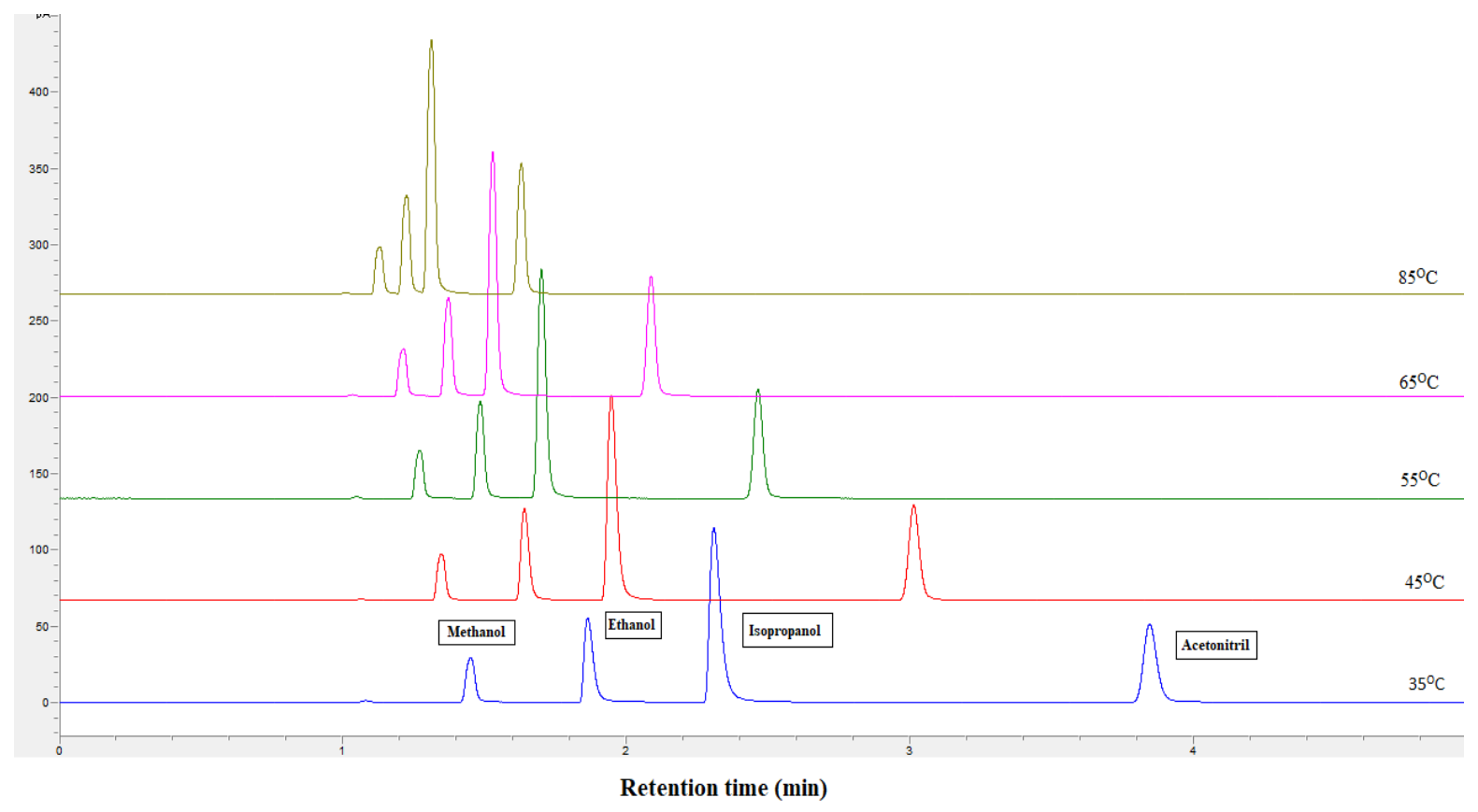

Figure 3. The chromatograms of analytes at different oven temperatures

\subsection{Validation of analytical method}

\subsubsection{Calibration curves}

Our experimental results showed that there is no significant difference between chromatograms of standards prepared with and without whole blood matrix. Therefore, we proceed to construct calibration curves by using standard solutions without blood matrix. After establishing the chromatographic conditions, separate calibration curves were prepared at methanol, ethanol, and isopropanol concentrations of $1.0-500 \mathrm{mg} / \mathrm{dL}$. For each concentration, three individual replicates were injected and the linearity was obtained with the correlation coefficients $\left(r^{2}\right)$ equal to $0.999,0.998$, and 0.999 for methanol, ethanol, and isopropanol, respectively. These correlation coefficients indicate that the proposed analytical method is appropriate for the determination of methanol, ethanol, and isopropanol over a wide concentration range. The limit of detection (LOD) and quantitation (LOQ) were 0.5 and $1.5 \mathrm{mg} / \mathrm{dL}$, respectively.

\subsubsection{Precision and accuracy}

The accuracy of the method was determined by recovery studies for methanol, ethanol, and isopropanol. Exact amounts of analytes were prepared at two concentration levels of 50 and $500 \mathrm{mg} / \mathrm{dL}$. The results show that recovery rate (98 to 102\%) falling within the recovery range 
recommended by AOAC International [2] at all two levels for all the three analytes, as shown in Table 1.

The method precision in term of repeatability were determined by six measurements of spiked samples with methanol, ethanol, and isopropanol at two concentration levels of 50 and $500 \mathrm{mg} / \mathrm{dL}$ (Table 1 ). The repeatability $(\mathrm{RSD}<0.1 \%)$ all met the requirements of AOAC International [2]. Therefore, the results of method precision showed that the method is precise within the acceptable limits.

Table 1. Accuracy for methanol, ethanol and isopropanol $(n=6)$

\begin{tabular}{ccccccc}
\hline & \multicolumn{2}{c}{ Methanol } & \multicolumn{2}{c}{ Ethanol } & \multicolumn{2}{c}{ Isopropanol } \\
\hline$C_{\text {spiked }}(\boldsymbol{m g} / \boldsymbol{d L})$ & 50.0 & 500.0 & 50.0 & 500.0 & 50.0 & 500.0 \\
$C_{\text {measured }}(\boldsymbol{m g} / \boldsymbol{d L})$ & $51.0 \pm 4.0$ & $502.5 \pm 4.3$ & $49.5 \pm 2.4$ & $498.2 \pm 5.1$ & $49.0 \pm 2.0$ & $499.3 \pm 5.0$ \\
Precision (RSD\%) & 4.5 & 5.0 & 2.9 & 6.1 & 1.9 & 5.2 \\
Recoveries (\%) & 102.0 & 100.4 & 98.0 & 99.6 & 98.0 & 99.8 \\
\hline
\end{tabular}

\subsection{Analytical results of blood and white spirit samples}

The validated method was applied to quantify trace levels of methanol, ethanol, and isopropanol in blood samples from seven patients with acute methanol poisoning and three white spirit samples in the Poison Control Center of Bach Mai Hospital in 2020 (Table 2). These white spirit samples were obtained from the patients' relatives. The results correlated well with the clinical course of intoxication.

Table 2. Concentrations of methanol, ethanol, and isopropanol in blood and white spirit samples

\begin{tabular}{cccc}
\hline Sample & $C_{\text {methanol }}(\mathbf{m g} / \mathbf{d L})$ & $C_{\text {ethanol }}(\mathbf{m g} / \mathbf{d L})$ & $C_{\text {isopropanol }}(\mathrm{mg} / \mathrm{dL})$ \\
\hline Patient blood 1 & 52.4 & - & - \\
Patient blood 2 & 260 & 535 & - \\
Patient blood 3 & 295 & - & 2.91 \\
Patient blood 4 & 4.56 & 106 & - \\
Patient blood 5 & 142 & - & - \\
Patient blood 6 & 233 & - & - \\
Patient blood 7 & 116 & - & - \\
White spirit 1 & $78 \%$ & - & - \\
White spirit 2 & $79 \%$ & $4 \%$ & - \\
White spirit 3 & $21 \%$ & $75 \%$ & \\
\hline
\end{tabular}

\section{CONCLUSION}

The present study describes a simple, fast, and cost-effective procedure for simultaneous determination of methanol, ethanol, and isopropanol in blood and alcohol samples by using HSGC-FID method. The analytical method was validated for accuracy, precision, reproducibility, and sensitivity. Our results revealed that HS-GC-FID could serve as a reference method for 
detection of trace amounts of alcohol impurities in biological fluids and beverages, which met the quality criteria for routine diagnostics as well as for forensic, toxicological, and analytical purposes. The procedure has been successfully applied in our routine clinical practices.

\section{REFERENCES}

[1]. L. O. Péres, R. W. C. Li, E. Y. Yamauchi, R. Lippi, J. Gruber, "Conductive polymer gas sensor for quantitative detection of methanol in Brazilian sugar-cane spirit", Food Chemistry, vol. 130, pp. 1105-1107, 2012.

[2]. AOAC, White spirit s. In Official methods of analysis of AOAC international, 15th Edition, pp. 739-750, 1990.

[3]. C.C. Kuo, Y.H. Wen, C.M. Huang, H.L. Wu, S.S. Wu, "A removable derivatization HPLC for analysis of methanol in Chinese liquor medicine", Journal of Food and Drug Analysis, vol. 10, pp. 101-106, 2002.

[4]. K. Lynam, Screen Beer by GC/MS Static Headspace with the Agilent Je W DB-624 Ultra Inert Capillary Column, Agilent Technologies.

[5]. P. F. Pereira, R.M.F. Sousa, R.A.A. Munoz, E.M. Richter, "Simultaneous determination of ethanol and methanol in fuel ethanol using cyclic voltammetry", Fuel, vol. 103, pp. 725729, 2013.

[6]. A. Shishov, A. Penkova, A. Zabrodin, K. Nikolaev, M. Dmitrenko, S. Ermakov, A. Bulatov, "Vapor permeation-stepwise injection simultaneous determination of methanol and ethanol in biodiesel with voltammetric detection", Talanta, vol. 148 (Supplement C), pp. 666-672, 2016.

[7]. B.J. Savary, A. Nuñez, "Gas chromatography-mass spectrometry method for determining the methanol and acetic acid contents of pectin using headspace solid-phase microextraction and stable isotope dilution", Journal of Chromatography A, vol. 1017, pp. 151-159, 2003.

[8]. G. C. Zhuang, Y. S. Lin, M. Elvert, V. B. Heuer, K. U. Hinrichs,"Gas chromatographic analysis of methanol and ethanol in marine sediment pore waters: Validation and implementation of three pretreatment techniques", Marine Chemistry, vol. 160, pp. 82-90, 2014.

[9]. M. L. Wang, J. T. Wang, Y. M. Choong, "A rapid and accurate method for determination of methanol in alcoholic beverage by direct injection capillary gas chromatography", Journal of Food Composition and Analysis, vol. 17, pp. 187-196, 2004.

[10].S. Kage, K. Kudo, H. Ikeda, N. Ikeda, "Simultaneous determination of formate and acetate in whole blood and urine from humans using gas chromatography-mass spectrometry", Journal of Chromatography B, vol. 805, pp. 113-117, 2004.

[11].M. Bursova, T. Hlozek and R. Cabala, "Simultaneous Determination of Methanol, Ethanol and Formic Acid in Serum and Urine by Headspace GC-FID", Journal of Analytical Toxicology, vol. 39, pp. 741-745, 2015. 


\title{
Xác định đổng thời methanol, ethanol và isopropanol trong mẫu máu và rượu
}

\author{
Vũ Anh Phuiơng ${ }^{1^{*}}$, Nguyễn Thị Ngân ${ }^{1}$, Đỗ Thị Trang ${ }^{1}$, Đinh Sơn Lương \\ Nguyễn Thị Ánh Hường ${ }^{2}$ Hoàng Quốc Anh ${ }^{2 *}$ \\ ${ }^{1}$ Trung tâm chống dộc, Bệnh viện Bạch Mai, Hà Nội, Việt Nam \\ ${ }^{2}$ Trường Đại học Khoa học Tự nhiên, Đại học Quốc gia Hà Nội, Hà Nội, Việt Nam
}

\section{Tóm tắt}

Sắc ký khí ghép nối detector ion hóa ngọn lửa và bộ lấy mẫu tự động không gian hơi (HSGC-FID) là phương pháp đơn giản và tiết kiệm để xác định đông thời methanol, ethanol và isopropanol trong mẫu máu và rượu. Trong nghiên cứu này, nhiệt độ ủ mẫu và thời gian ủ mẫu tối ưu lân lượt là $70^{\circ} \mathrm{C}$ và 20 phút. Nồng độ của các chất phân tích được xác định bằng phương pháp nội chuẩn sử dụng chất nội chuẩn là acetonitrile. Khoảng tuyến tính của các chất nằm trong khoảng từ 1 đến $500 \mathrm{mg} / \mathrm{dL}$. Phương pháp đã được thẩm định với độ chính xác cao thông qua hiệu suất thu hồi đạt $>98 \%$ và độ chụm tốt với độ lệch chuẩn tương đối $<0,1 \%$ với cả mẫu máu và mẫu rượu. Giới hạn phát hiện của cả ba chất phân tích đạt $<0,5 \mathrm{mg} / \mathrm{dL}$. Phương pháp phân tích này rất đơn giản, thích hợp được sử dụng như phương pháp phân tích thường quy tại các phòng thí nghiệm thực phẩm, sinh hóa lâm sàng và pháp $\mathrm{y}$.

Tư khóa: Methanol, ethanol, isopropanol, mẫu máu, mẫu rượu, GC-FID. 